\title{
Upaya Peningkatan Kesehatan Lansia Melalui Pendidikan Kesehatan Massage Kaki di Posyandu Lansia Lenggono
}

\author{
Maula Mar'atus Solikhah ${ }^{1}$, Mutiara Dewi L ${ }^{2}$ \\ Prodi D3 Keperawatan Universitas Kusuma Husada Surakarta \\ maula.mar'atus@ukh.ac.id
}

\begin{abstract}
Abstrak
Penyakit hipertensi merupakan penyakit yang dikenal dengan istilah silent killer karena gejala hanya sedikit, bahkan terkadang tanpa gejala. Salah satu terapi nonfarmakologis yang bisa diberikan pada penderita hipertensi adalah massage kaki. Tujuan kegiatan pengabdian masyarakat ini adalah untuk meningkatkan pengetahuan lansia tentang massage kaki. Target kegiatan ini adalah kelompok lansia posyandu lenggono. Metode pelaksanaan dengan ceramah, tanya jawab dan demonstrasi melalui daring online. Tahapan kegiatan meliputi pertemuan dengan kader kesehatan posyandu lansia, persiapan alat dan materi, pelaksanaan pendidikan kesehatan dan monitoring serta evaluasi. Hasil kegiatan yaitu terdapat peningkatan pengetahuan lansia tentang pijat kaki dari nilai rata-rata 46,4 menjadi 82,4. Rekomendasi dari kegiatan ini adalah monitoring dan evaluasi hasil kegiatan melalui kerjasama dengan kader dan petugas kesehatan.
\end{abstract}

Kata kunci : lansia, hipertensi, massage kaki

\begin{abstract}
Hypertension is known as the silent killer disease because the symptoms are few, sometimes it does not cause any symptoms at all. One of the non-pharmacological therapies that can be given to people with hypertension is foot massage. The aim of this community service activity is to increase the knowledge of the elderly about foot massage. The target of this activity is the elderly group of Posyandu Lenggono. Implementation of this community service activity includes lecture, question and answer, and online discussion. The activity stages include meeting with elderly health cadres, preparation of tools and materials, implementation of health education and monitoring, and evaluation. The result of this activity shows the increasing knowledge of the elderly about foot massage from an average value of 46.4 to 82.4. Recommendations that can be taken from this activity are monitoring and evaluation the results of this community service activity where collaborate with cadres and health workers.
\end{abstract}

Key words: elderly, hypertension, foot massage 


\section{PENDAHULUAN}

Salah satu penyakit kronis yang di diderita oleh masyarakat serta membutuhkan waktu lama untuk proses kesembuhannya adalah hipertensi. Angka kejadian hipertensi dimasyarakat harus mendapatkan perhatian yang serius terutama dari pihak pelayanan kesehatan. Di seluruh dunia, hampir 1 miliar orang atau sekitar seperempat dari populasi orang dewasa menyandang tekanan darah tinggi. Jumlah ini cenderung meningkat setiap tahunnya, di Inggris (UK) penyakit ini diperkirakan mengenai lebih dari 16 juta orang. Di Inggris (England) 34\% pria dan 30\% wanita menyandang tekanan darah tinggi diatas 140/90 mmHg dan sedang menjalani pengobatan (Patar, 2011).

Penanganan hipertensi dilakukan dengan farmakologis dan nonfarmakologis. Penanganan farmakologis yaitu dengan menggunakan obat-obat anti hipertensi dan terapi non farmakologi yaitu dengan memodifikasi gaya hidup atau kombinasi keduanya. Pada saat obat anti-hipertensi diperlukan, pengobatan non-farmakologi dapat digunakan sebagai pelengkap untuk mendapatakan efek pengobatan yang lebih baik (Dalimartha, 2008).

Terapi non farmakologis yang bisa dilakukan untuk menurunkan tekanan darah salah satunya yaitu terapi massage (pijat) kaki. Teknik pemijatan pada titik tertentu dapat menghilangkan sumbatan dalam darah sehingga aliran darah dan energi di dalam tubuh kembali lancar (Dalimartha, 2008). Penelitian sebelumnya menjelaskan tentang pengaruh pijat kaki dengan minyak esensial lavender pada pasien hipertensi menunjukkan bahwa pijat kaki dapat memperlancar aliran darah balik dari kaki menuju ke jantung. Efek relaksasi yang ditimbulkan saat pijat kaki semakin diperkuat oleh minyak esensial lavender. Dampak pijat kaki dengan minyak esensial lavender terhadap tubuh adalah stimulasi sistem saraf parasimpatis dan mengurangi ketegangan otot sehingga dapat menurunkan tekanan darah. Hasil penelitian Herliawati (2011) menunjukkan bahwa pijat kaki dengan minyak esensial lavender berpengaruh terhadap penurunan tekanan darah. Kendala yang dihadapi saat terapi pijat kaki adalah pengadaan minyak esensial lavender dan harganya juga tidak murah. Oleh karena itu alternatif dari penulis yaitu menggunakan baby oil yang mudah didapatkan dan dijangkau oleh masyarakat semua kalangan.

Berdasarkan data dari kader di Posyandu Lansia Lenggono, lansia dan keluarga sebagian besar belum mengetahui tentang pijat kaki untuk menurunkan tekanan darah pada lansia yang mengalami hipertensi ringan dan sedang. Keadaan ini menunjukkan bahwa kurangnya pendidikan kesehatan berkaitan dengan tindakan yang bisa diberikan kepada lansia 
dengan hipertensi. Keluarga sebagai caregiver juga banyak yang belum mengetahui cara merawat lansia dengan hipertensi. Berdasarkan uraian di atas maka perlu dilakukan kegiatan pengabdian masyarakat tentang pemberian pendidikan kesehatan massage kaki untuk meningkatkan pengetahuan lansia dan keluarganya berkaitan dengan tindakan massage kaki

\section{MASALAH}

Berdasarkan uraian latar belakang diatas maka dapat dirumuskan masalah dalam pengabdian masyarakat ini adalah "Bagaimana upaya peningkatan kesehatan lansia melalui pendidikan kesehatan massage kaki di Posyandu Lansia Lenggono?

\section{METODE}

Metode yang digunakan dalam kegiatan pengabdian masyarakat ini melalui daring yaitu group Whatshap posyandu lansia dan video kegiatan yang diupload melalui youtube. Absensi kegiatan, pre and post test pengetahuan dilakukan menggunakan google form dan pemberian poster massage kaki secara online setelah selesai acara.

\section{HASIL DAN PEMBAHASAN}

1) Hasil

Pengabdian masyarakat ini telah dilakukan di posyandu lansia lenggono yang beralamat di Sibela Rt 03 Rw 25 dan merupakan wilayah kerja Puskesmas Sibela Kelurahan Mojosongo Kecamatan Jebres Kota Surakarta. Sasaran kegiatan ini sejumlah 25 lansia di kelompok posyandu lansia lenggono. Kegiatan ini dilakukan secara daring online karena dari Pihak Puskesmas belum membolehkan untuk pertemuan secara langsung berkaitan kondisi pandemi covid 19.

Kegiatan pengabdian masyarakat ini dilakukan bersama mahasiswa melalui group Whatshap dengan pemberian video yang sudah dibuat dan diupload melalui youtube dengan alamat sebagai berikut : https://www.youtube.com/watch?v=_vsQcpVkrCo\&list=PLG_JjZ5UXdOofYOzSZuor6Pjjov OVkbJY\&index $=4$. Setelah selesai kegiatan peserta diberikan poster secara online. 


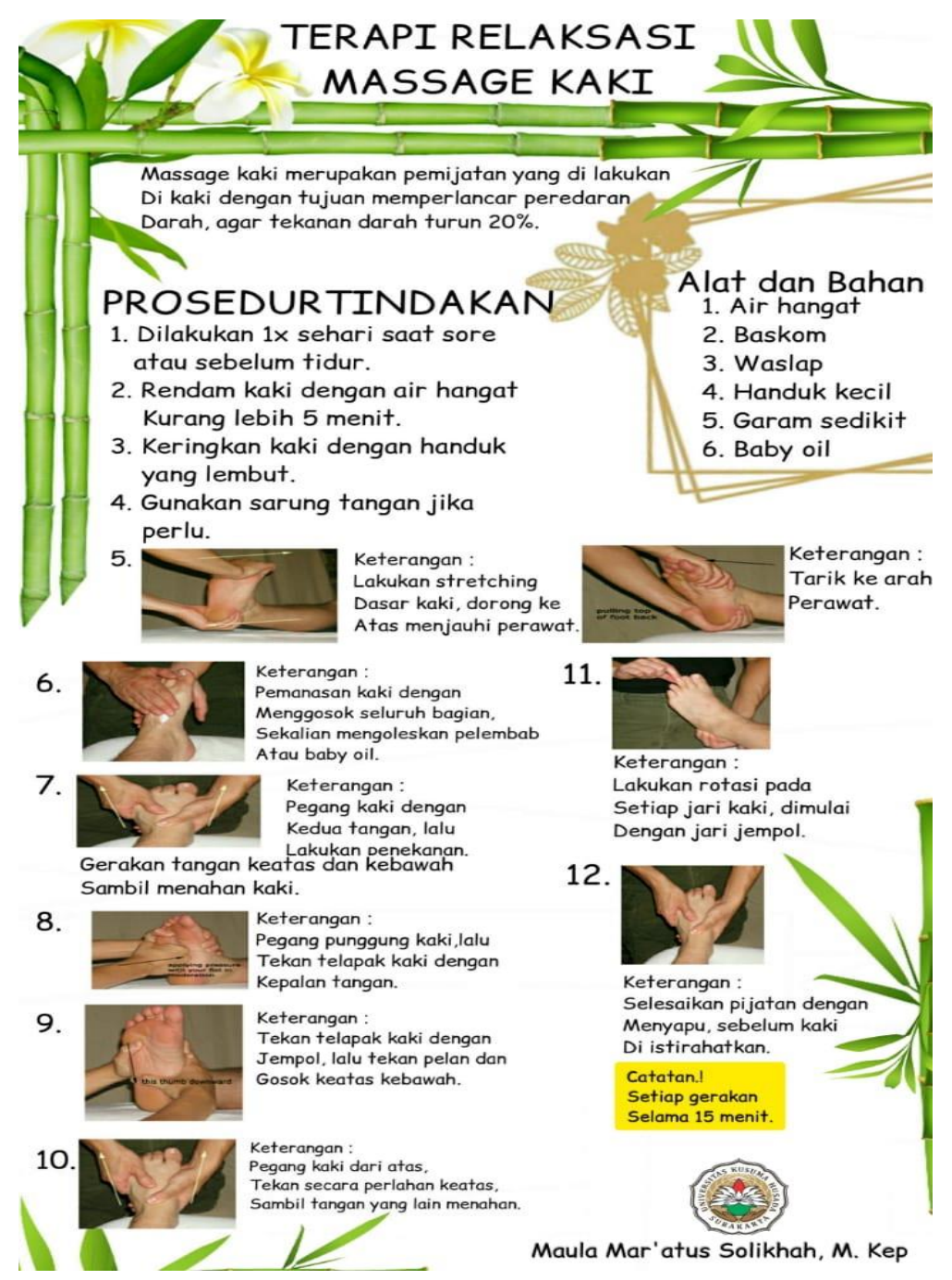

Gambar 1. Poster kegiatan

Evaluasi pengetahuan diberikan secara online baik pre test dan post test dengan google form didapatkan kenaikan skor pengetahuan dari nilai rata-rata 46,4 menjadi 82,4. Kegiatan penyuluhan berjalan dengan lancar dan peserta antusias dan aktif bertanya. Kegiatan dimulai pukul 08.00 dan berakhir sampai pukul 12.00 WIB. Semua peserta mengikuti acara dari awal sampai dengan akhir dengan baik.

\section{2) Pembahasan}

Kelompok lansia merupakan kelompok rentan untuk mengalami penyakit hipertensi. Hal ini terjadi karena proses degeneratif yang dialami terjadinya perubahan fungsi organ tubuh akibat kerusakan sel serta perubahan elastisitas pembuluh darah yang bisa berhubungan dengan aterosklerosis. Penatalaksanaan hipertensi pada kelompok lansia dapat dilakukan baik secara farmakologid dan nonfarmakologis. Akan tetapi yang terjadi di masyarakat kurang 
mengenal dan mengetahui berkaitan terapi nonfarmakologi untuk pasien hipertensi. Terapi nonfarmakologi yang dapat diberikan kepada kelompok lansia hipertensi yaitu terapi massage kaki, terapi relaksasi, aktivitas fisik, terapi aktivitas fisik, tidak merokok, mengurangi konsumsi garam dan menerapkan pola hidup sehat (Vamvakis, 2017, Hedayati, 2011, Anderson, 2010).

Pemilihan pemberian terapi pijat kaki pada kelompok lansia hipertensi didasarkan pada beberapa penelitian sebelumnya. Pemberian terapi pijat kaki dapat memberikan efek relaksasi pada bagian tubuh yang dipijat serta memberikan sirkulasi dan cairan tubuh yang berlangsung tanpa hambatan,memasok nutrisi dan oksigen ke sel tubuh sehingga kondisi ogan tubuh yang terdiri dari sejumlah sel akan kembali ke kondisi normal. Menurut Khoiriyah \& Chanif (2017) pemberian pijat kaki untuk pasien hipertensi memberikan pengaruh pada sirkulasi darah ke seluruh tubuh, meningkatkan kenyamanan, memberikan relaksasi secara fisik dan psikis sehingga terjadi penurunan tekanan darah. Selain itu juga memberikan penurunan aktivitas sistem saraf simpatis sehingga mengakibatkan penurunan tekanan darah.

Berkaitan dengan masalah yang terdapat di kelompok lansia posyandu lansia lenggono bahwa sebagian besar lansia belum mengetahui tentang terapi pijat kaki sebagai terapi nonfarmakologis pada pasien hipertensi. Sebagai bentuk upaya peningkatan kesehatan kelompok lansia maka dilakukan pendidikan kesehatan mengenai pijat kaki. Pendidikan kesehatan yang diberikan dengan tujuan peningkatan pengetahuan pasien berkaitan pijat kaki. Menurut Kumar (2015) kunci keberhasilan dari pendidikan kesehatan adalah komunikasi dua arah yang aktif serta komunikasi yang berkelanjutan dengan petugas kesehatan.

Hasil pengabdian masyarakat dapat dilihat dari peningkatan pengetahuan lansia berkaitan dengan terapi pijat kaki dari nilai rata-rata 46,4 menjadi 82,4. Hal ini sejalan dengan Prasetiya (2015) bahwa pemberian pendidikan kesehatan efektif meningkatkan pengetahuan. Pemberian pendidikan kesehatan ini mendapatkan respon yang baik dari ketua RW dan segenap petugas kesehatan setempat, kader kesehatan dan lansia di kelompok posyandu lenggono dengan dibuktikan keaktifan peserta ketika proses pelaksanaan kegiatan.

Gambaran pelaksanaan kegiatan yaitu sebelum pelaksanaan pendidikan kesehatan melalui daring online. Tim pengabdian masyarakat melakukan persamaan persepsi dan pembagian tugas berkaitan dengan pelaksanaan kegiatan pengabdian ini. Tim melakukan koordinasi dengan perawat Puskesmas Sibela untuk memberikan dukungan dan pengarahan kepada kader posyandu lansia lenggono sebagai pendamping/fasilitator lansia dalam 
mengikuti rangkaian kegiatan pengabdian masyarakat, baik dari mulai pengisian pre test, pemutaran video dan pemngambilan data post tes. Petugas Puskesmas memberikan dukungan dengan menggerakkan semua kader posyandu lansia lenggono untuk membantu kegiatan ini. Kader kesehatan posyandu lansia ikut terlibat aktif dalam kegitan ini dengan cara mengikuti kegiatan pengabdian ini secara daring dan melakukan kegiatan juga secara luring berupa kunjungan kepada lansia yang membutuhkan bantuan teknis ketika mengikuti kegiatan ini dengan tetap menggunakan protokol kesehatan. Ketika pelaksanaan kegiatan pengabdian ini, ketika ada lansia yang mengalami kendala langsung menghubungi kader yang terdekat dengan rumah lansia untuk meminta bantuan. Hasil kegiatan tidak semua lansia meminta bantuan kader dalam pelaksanaan kegiatan tersebut. Mayoritas sudah bisa secara mandiri dengan dibantu keluarga. Hanya ada bebrapa saja yang membutuhkan kunjungan dan pendampingan.

Gambaran pelaksanaan kegiatan ini diawali dengan penjelasan materi menggunakan metode ceramah dan demontrasi dengan media video yang sudah di upload di youtube. Setelah selesai kegiatan peserta diberikan pos test secara melalui daring online. Kegiatan ini membutuhkan tindak lanjut dan kerjasama dengan kader dan petugas kesehatan setempat sehingga kegiatan bisa berkelanjutan dan memberikan banyak manfaat untuk kelompok lansia khusunya yang memiliki penyakit hipertensi.

\section{KESIMPULAN}

Kesimpulan yang dapat diambil dari kegiatan pengabdian masyarakat pendidikan kesehatan massage kaki pada kelompok posyandu lansia lenggono ini adalah terdapat peningkatan pengetahuan lansia berkaitan dengan terapi pijat kaki dari nilai rata-rata 46,4 menjadi 82,4.

\section{DAFTAR PUSTAKA}

Anderson, D. et. a. (2010). Regular slow-breathing exercise effects on blood pressure and breathing patterns at rest. Journal of Human Hypertension, 24, 807-813.

Dalimartha, et. a. (2008). Care yourself hipertensi. Penebar Plus.

Hedayati, S. S. et. a. (2011). Non-pharmacological aspects of blood pressure management: what are the data? Kidney Int, 79(10), 1061-1070.

Herliawati. (2011). Pengaruh Masase Kaki Dengan Minyak Esensial Lavender Terhadap 
Penurunan Tekanan Darah.Penderita hipertensi primer usia 45-59 tahun Di kelurahan timbangan kecamatan indralaya utara kabupaten ogan ilir.

Khoiriyah \& Chanif. (2017). Penurunan tekanan Darah pada Pasien Hipertensi berbasis Pijat Refleksi. Prosiding Seminar Nasional: Universitas Muhammadiyah Semarang.

Kumar, S. (2015). Hypertension Management Through Patient Education. University of San Fransisco.

Patar. (2011). Pengaruh Pijat Refleksi Kaki Terhadap Penurunan Tekanan Darah Pada Penderita Hipertensi Di Desa Kasindir Kecamatan Jorlang Hataran Kabupaten Simalungun.

Prasetiya, C. H. (2015). Efektifitas pendidikan kesehatan terhadap peningkatan pengetahuan keluarga tentang hipertensi. Mutiara Medika, 15(1), 67 - 74.

Vamvakis, A. et. a. (2017). Beneficial effects of nonpharmacological interventions in the management of essential hypertension. Journal of the Royal Society of Medicine Cardiovascular Disease, 6, 1-6. 